\title{
Description of Mathematical Problem-Solving Skills Reviewed from Student Learning Independence
}

\author{
Malim Muhammad ${ }^{1}$, Ayu Sagita ${ }^{2}$ \\ \{malim.muhammad@gmail.com ${ }^{1}$, ayusagitap22@gmail.com $\left.{ }^{2}\right\}$ \\ Department of Mathematics Education, Faculty of Teacher Training \\ and Education, Universitas Muhammadiyah Purwokerto
}

\begin{abstract}
This research aims to describe mathematical problem-solving skills regarding the learning independence of Muhammadiyah Sempor vocational school students during the Covid-19 pandemic. This research includes a qualitative descriptive study. Data is obtained from learning independence questionnaires, tests of mathematical problemsolving skills, and interviews. Students are grouped into three groups based on the results of the learning independence questionnaire, namely students of the high, medium, and low learning independence groups. Selection of research subjects using purposive sampling techniques. From the data presented, the data validity test was conducted using triangulation techniques. Data obtained in the form of test results and interviews are used to describe students' mathematical problem-solving skills using the triangulation technique. The results showed that students with a high learning independence group were able to meet all indicators, i.e., understanding problems, planning solutions, executing plans, and re-examining. In the learning independence group, learning can meet three indicators, namely, understanding the problem, planning a solution, and implementing a plan. Meanwhile, the low learning independence group can meet one indicator that is understanding the problem.
\end{abstract}

Keywords: Mathematical problem-solving skills, Learning independence, SMK Muhammadiyah Sempor

\section{Introduction}

During the Covid-19 pandemic, the learning process in Indonesia has shifted. In everyday life, we often encounter a problem, so it takes away from solving the problem. Likewise, mathematics also has problems that require a way or strategy to solve them. Thus, students need to master mathematical problem-solving skills. Because the ability to solve mathematical problems is the ability of students to overcome difficulties in solving problems or math problems Allo et al. [1], according to Kesumawati (Mawaddah and Anisah, 2015) Through mathematical problem-solving skills, students can devise mathematical models, determine solving strategies, are able to identify known and asked elements and can double-check the answers obtained [2].

In addition to mastering mathematical problem-solving skills, students are also required to have an attitude of learning independence. Especially now still in the condition of covid-19 where students need an independent attitude in learning. Rohman \& Herdiman (Ansori \& Herdiman, 2019) suggests that learning independence is the ability of students to practice by studying the subject matter without the help of others so as to reduce students' difficulties when solving given problems [3]. To achieve mathematical problem-solving skills and solve these 
problems, students need good behavior, one of which is learning independence. This is in line with research (Sulistyani \& Roza, 2020), which states that learning independence can be used as one factor affecting learners' mathematical problem-solving ability [1].

SMK Muhammadiyah Sempor is the only vocational high school located in the Sempor District of Kebumen Regency. SMK Muhammadiyah Sempor is located on Jalan KlampokGombong Sampang Jurang Jero RT 03 RW 06 Sempor Subdistrict. Based on the researchers' discussions with teachers, the results showed that when the teacher gave examples of problems that were different from the previous issue, students found it difficult to solve them and were still fixated with the way the teacher's solution. The independence of students in learning is still not maximal. This can be seen when students are less active in participating in learning activities, and when teachers give questions to students, many students do not believe in their own abilities so that which affects the high level of mathematical problem-solving ability of students. The purpose of this study is to describe mathematical problem-solving skills in view of the learning independence of Muhammadiyah Sempor vocational school students during the covid-19 pandemic.

Mathematical problem-solving skills are more focused where students process existing information so as to solve mathematical problems. So in this ability, students do not directly solve problems, but there must be stages that must be implemented. According to Polya (Purnamasari \& Setiawan, 2019), the location of solving problems is to know the problem, make a plan, and double-check the steps to get the final result [4]. The ability to solve mathematical problems is an ability to understand problems in math subjects that are considered complicated and difficult to do [5]. Math problem solving is the way that students do when going to look for answers to math problems that come from books, the internet, and real problems in everyday life.

The indicators of mathematical problem-solving abilities used by researchers are:

1) Understanding the problem. Students are able to deepen the crisis and identify the known elements and what is asked in the question.

2) Planning a solution. Students are able to determine the strategies and formulas that will be used to answer the given problem. Students can also illustrate images based on issues if the problem is a matter of the story.

3) Implementing the plan. Students can implement the strategies (settlement steps) that have been prepared at the stage of planning the completion to obtain answers.

4) Re-examining, students can draw conclusions on the answers that have been done whether the answers are in accordance with what is asked.

Independence is the attitude possessed by students so that students do not depend on others to achieve their desires. In this case, students can effectively carry out their learning tasks and do their learning activities independently [6]. In addition, Schunk (Sariningsih \& Kadarisma, 2016) states that a person who has learning independence will pursue his long-term task until the task is completed and has the ability to manage his motivation, not only external motivators but also internal motivators [7].

From the description above, the researcher took the following indicators of learning independence:

1) Initiative means the attitude or behavior of students who make themselves driven to do something on their own and without orders from others.

2) By determining learning strategies, students create their own learning schedules with discipline and consistency, looking for learning resources other than teachers and friends and self-study. 
3) Student learning activities, independent learning activities are owned and carried out by students to facilitate their learning.

4) Evaluation, students examine the learning outcomes that have been done, as well as assess the advantages and disadvantages that exist in students in order to be better at the next activities and learning outcomes.

5) In interpersonal skills, students have good confidence when dealing with others that is smooth and able to communicate with others and express their opinions without fear of being wrong [8].

\section{Research Methods}

The type of research used is qualitative descriptive. Qualitative descriptive research is used to describe problem-solving skills in view of the learning independence of students of class $\mathrm{X}$ TKJ SMK Muhammadiyah Sempor on Trigonometric material. The research implementation time was carried out during the even semester of the 2020/2021 school year. The number of class X SMK Muhammadiyah Sempor there are two classes. The class used as a research subject is class X TKJ based on direction from a math teacher. The number of students of class X TKJ is as many as 33 students. But in its implementation, only 25 students left for school at the time of the study. Instruments used for the study include learning independence questionnaires, tests of mathematical problem-solving skills, and interview guidelines. The results of the three instruments are used to infer students' mathematical problem-solving abilities because of learning independence. In data collection techniques, appropriate methods are needed following the problems to be examined. The methods that researchers will use are Questionnaires, Tests, Interviews, and Documentation [9].

From the data presented, the data validity test was conducted using triangulation techniques. Triangulation means using several different techniques to the same data source, but the goal is not to seek the truth but rather to improve the researcher's understanding of the data and its facts. Triangulation was used in this study using the triangulation technique that uses various data sources such as questionnaires, tests, and then checked with interviews. The triangulation measures in this study are as follows [10]:

1) Distributing learning independence questionnaires to students of class $X$ TKJ SMK Muhammadiyah Sempor to categorize students into high, medium, and low learning independence each 3 in each category

2) Providing a test of mathematical problem-solving ability with the material tested is Trigonometry

3) Interviewed nine respondents

\section{Results and Discussion}

\section{Results of Student Learning Independence Questionnaire}

Data from the students' learning independence questionnaire obtained from 25 respondents quantitatively showed that the total score of questionnaire results amounted to 1606 with an average of 64.24 and a standard deviation of 9,497. The minimum score is 42 , and the maximum score is 79 . Based on the average results and standard deviation results of the Learning Independence (KB) questionnaire, used to group students into three groups according to 
predetermined criteria, it is necessary to calculate the average plus the standard deviation, and the average is reduced the standard deviation.

\section{Results of Mathematical Problem-Solving Skills Tests and interviews}

The student's mathematical problem-solving abilities are described based on the results of the test description of mathematical problem-solving abilities with trigonometric materials. The test consists of three questions, with each question consisting of 4 questions according to the indicator. Students answer questions on the answer sheet.

Table 1. Triangulation of students' mathematical problem-solving skills and interviews

\begin{tabular}{|c|c|c|c|c|}
\hline Respond & $\begin{array}{c}\text { Troubleshooting } \\
\text { steps }\end{array}$ & Test results & Interview & Information \\
\hline \multirow[t]{4}{*}{$\begin{array}{l}\text { High Learning } \\
\text { Independence } 1\end{array}$} & $\begin{array}{l}\text { Understanding } \\
\text { the Problem }\end{array}$ & $\begin{array}{l}\text { Students are able to } \\
\text { understand the problem. } \\
\text { This is shown by students } \\
\text { being able to write down } \\
\text { anything that is known and } \\
\text { asked in the question. }\end{array}$ & $\begin{array}{l}\text { Students can re- } \\
\text { explain what is } \\
\text { known and asked } \\
\text { clearly and use their } \\
\text { own language. }\end{array}$ & Data valid \\
\hline & $\begin{array}{ll}\text { Planning } & \text { a } \\
\text { Settlement }\end{array}$ & $\begin{array}{l}\text { Students can plan an initial } \\
\text { plan or strategy that will } \\
\text { be used to solve existing } \\
\text { problems by making } \\
\text { illustrations according to } \\
\text { the problem and writing } \\
\text { the formula to be used at a } \\
\text { later stage. }\end{array}$ & $\begin{array}{l}\text { Students re-explain } \\
\text { how the original } \\
\text { plan will be used to } \\
\text { go to the next stage. }\end{array}$ & Data valid \\
\hline & $\begin{array}{l}\text { Implementing a } \\
\text { plan }\end{array}$ & $\begin{array}{l}\text { Students can perform } \\
\text { calculations with the } \\
\text { correct steps according to } \\
\text { the previously made plan. }\end{array}$ & $\begin{array}{l}\text { Students are able to } \\
\text { re-explain the } \\
\text { completion steps } \\
\text { when performing } \\
\text { calculations. }\end{array}$ & Data valid \\
\hline & Check Back & $\begin{array}{l}\text { Students have re- } \\
\text { examined the answer to } \\
\text { the question by drawing } \\
\text { conclusions. }\end{array}$ & $\begin{array}{l}\text { Students are able to } \\
\text { re-mention the } \\
\text { conclusions } \\
\text { obtained. }\end{array}$ & Data valid \\
\hline $\begin{array}{l}\text { High Learning } \\
\text { Independence } 2\end{array}$ & $\begin{array}{l}\text { Understand the } \\
\text { problem }\end{array}$ & $\begin{array}{l}\text { Students are able to } \\
\text { understand the problem. } \\
\text { This is shown by students } \\
\text { being able to write down } \\
\text { anything that is known and } \\
\text { asked. }\end{array}$ & $\begin{array}{l}\text { Students can re- } \\
\text { mention what is } \\
\text { known and asked in } \\
\text { the question clearly. }\end{array}$ & Data valid \\
\hline
\end{tabular}




\begin{tabular}{|c|c|c|c|c|}
\hline & $\begin{array}{l}\text { Planning } \quad \text { a } \\
\text { settlement }\end{array}$ & $\begin{array}{l}\text { Students are already able } \\
\text { to plan the solution by } \\
\text { drawing illustrations } \\
\text { according to the problem } \\
\text { clearly. }\end{array}$ & $\begin{array}{l}\text { Students are able to } \\
\text { explain again how } \\
\text { the initial plan will } \\
\text { be used to the next } \\
\text { stage. }\end{array}$ & Data valid \\
\hline & $\begin{array}{l}\text { Implementing a } \\
\text { plan }\end{array}$ & $\begin{array}{l}\text { Students are already able } \\
\text { to carry out calculations } \\
\text { with systematic measures. }\end{array}$ & $\begin{array}{l}\text { Students can re- } \\
\text { explain how } \\
\text { problem-solving } \\
\text { steps are using their } \\
\text { own language. }\end{array}$ & Data valid \\
\hline & Recheck & $\begin{array}{l}\text { Students can draw } \\
\text { conclusions. But on } \\
\text { question number } 3, \\
\text { students are not yet right } \\
\text { in drawing conclusions. }\end{array}$ & $\begin{array}{lr}\begin{array}{l}\text { Students } \\
\text { mention }\end{array} & \begin{array}{r}\text { can } \\
\text { the }\end{array} \\
\text { conclusions they } \\
\text { reached. } \\
\text { students are } \\
\text { confused still } \\
\text { drawing conclusions } \\
\text { on question number } \\
\text { 3. }\end{array}$ & Data valid \\
\hline $\begin{array}{l}\text { High Learning } \\
\text { Independence } 3\end{array}$ & $\begin{array}{l}\text { Understand the } \\
\text { problem }\end{array}$ & $\begin{array}{l}\text { Students have written } \\
\text { down what is known and } \\
\text { asked briefly and clearly. }\end{array}$ & $\begin{array}{l}\text { Students are able to } \\
\text { re-mention what is } \\
\text { known and asked in } \\
\text { the question item. }\end{array}$ & Data valid \\
\hline & $\begin{array}{l}\text { Planning a } \\
\text { settlement }\end{array}$ & $\begin{array}{l}\text { Students have written the } \\
\text { completion plan by } \\
\text { drawing illustrations } \\
\text { according to the problem } \\
\text { and writing the formula } \\
\text { that will be used at a later } \\
\text { stage. }\end{array}$ & $\begin{array}{l}\text { Students can re- } \\
\text { explain how the } \\
\text { original plan and } \\
\text { formula were used. }\end{array}$ & Data valid \\
\hline & $\begin{array}{l}\text { Implementing a } \\
\text { plan }\end{array}$ & $\begin{array}{l}\text { Students perform } \\
\text { calculations correctly and } \\
\text { systematically in solving } \\
\text { problems. }\end{array}$ & $\begin{array}{l}\text { Students can re- } \\
\text { explain the steps } \\
\text { taken to solve the } \\
\text { problem. }\end{array}$ & Data valid \\
\hline
\end{tabular}




\begin{tabular}{|c|c|c|c|c|}
\hline & Recheck & $\begin{array}{l}\text { Students can draw } \\
\text { conclusions and be } \\
\text { confident of the answers } \\
\text { obtained. }\end{array}$ & $\begin{array}{l}\text { Students } \\
\text { mention } \\
\text { conclusion of } \\
\text { answer the } \\
\text { question. }\end{array}$ & Data valid \\
\hline \multirow[t]{4}{*}{$\begin{array}{l}\text { Independence } \\
\text { of Learning Is } 1\end{array}$} & $\begin{array}{l}\text { Understand the } \\
\text { problem }\end{array}$ & $\begin{array}{l}\text { Students can write down } \\
\text { what they are asked and } \\
\text { asked questions. }\end{array}$ & $\begin{array}{l}\text { Students are able to } \\
\text { re-mention what is } \\
\text { known and asked in } \\
\text { the question item. }\end{array}$ & Data valid \\
\hline & $\begin{array}{l}\text { Planning } \quad \mathrm{a} \\
\text { settlement }\end{array}$ & $\begin{array}{l}\text { Students can make the } \\
\text { initial plan used by } \\
\text { making illustrations in the } \\
\text { form of images according } \\
\text { to the problem but do not } \\
\text { write the formula to be } \\
\text { used. }\end{array}$ & $\begin{array}{l}\text { Students } \\
\text { mention the initial } \\
\text { plan to get to the } \\
\text { next stage. }\end{array}$ & Data valid \\
\hline & $\begin{array}{l}\text { Implementing a } \\
\text { plan }\end{array}$ & $\begin{array}{l}\text { Students write down the } \\
\text { settlement steps correctly. }\end{array}$ & $\begin{array}{l}\text { Students can re- } \\
\text { explain problem- } \\
\text { solving steps. }\end{array}$ & Data valid \\
\hline & Recheck & $\begin{array}{l}\text { Students can re-examine } \\
\text { by drawing conclusions on } \\
\text { question number 1. At } \\
\text { number } 2 \text {, the student does } \\
\text { not draw conclusions. And } \\
\text { number } 3 \text { students are still } \\
\text { wrong in drawing } \\
\text { conclusions. }\end{array}$ & $\begin{array}{l}\text { Students cannot } \\
\text { draw conclusions on } \\
\text { question number } 2 \\
\text { and are unsure when } \\
\text { drawing conclusions } \\
\text { on question number } \\
\text { 3. }\end{array}$ & Data valid \\
\hline \multirow[t]{2}{*}{$\begin{array}{l}\text { Independence } \\
\text { of Learning Is } 2\end{array}$} & $\begin{array}{l}\text { Understand the } \\
\text { problem }\end{array}$ & $\begin{array}{l}\text { Students have written } \\
\text { down important things } \\
\text { that are known and asked } \\
\text { in the question item. }\end{array}$ & $\begin{array}{l}\text { Students can re- } \\
\text { mention important } \\
\text { information } \\
\text { contained in the } \\
\text { problem item. }\end{array}$ & Data valid \\
\hline & $\begin{array}{l}\text { Planning } \quad \mathrm{a} \\
\text { settlement }\end{array}$ & $\begin{array}{l}\text { Students have made an } \\
\text { initial plan by making } \\
\text { illustrations in the form of } \\
\text { images but do not write } \\
\text { the formula to be used. }\end{array}$ & $\begin{array}{l}\text { Students explain the } \\
\text { initial plan that will } \\
\text { be used at a later } \\
\text { stage. }\end{array}$ & Data valid \\
\hline
\end{tabular}




\begin{tabular}{|c|c|c|c|c|}
\hline & $\begin{array}{l}\text { Implementing a } \\
\text { plan }\end{array}$ & $\begin{array}{l}\text { Students can write down } \\
\text { the calculation steps } \\
\text { correctly. }\end{array}$ & $\begin{array}{l}\text { Students are able to } \\
\text { re-explain the } \\
\text { problem-solving } \\
\text { stages with their } \\
\text { own language. }\end{array}$ & Data valid \\
\hline & Recheck & $\begin{array}{l}\text { Students can double- } \\
\text { check between the answer } \\
\text { and the question by } \\
\text { drawing conclusions only } \\
\text { in the number } 2 \text { question } \\
\text { item only. }\end{array}$ & $\begin{array}{l}\text { Students can only } \\
\text { draw conclusions on } \\
\text { question number } 2 \\
\text { only, and others are } \\
\text { still confused. }\end{array}$ & Data valid \\
\hline \multirow[t]{4}{*}{$\begin{array}{l}\text { Learning } \\
\text { Independence } \\
\text { Is } 3\end{array}$} & $\begin{array}{l}\text { Understand the } \\
\text { problem }\end{array}$ & $\begin{array}{l}\text { Students have written } \\
\text { down information that is } \\
\text { known and asked } \\
\text { appropriately. }\end{array}$ & $\begin{array}{l}\text { Students are able to } \\
\text { re-mention what is } \\
\text { known and asked in } \\
\text { the question item. }\end{array}$ & Data valid \\
\hline & $\begin{array}{ll}\text { Planning } & \text { a } \\
\text { settlement }\end{array}$ & $\begin{array}{l}\text { Students are able to write } \\
\text { the initial plan for the next } \\
\text { stage by making } \\
\text { illustrations of the image } \\
\text { but not writing the formula } \\
\text { to be used. }\end{array}$ & $\begin{array}{l}\text { Students can explain } \\
\text { how the initial plan } \\
\text { will be used to get to } \\
\text { the next stage well. }\end{array}$ & Data valid \\
\hline & $\begin{array}{l}\text { Implementing a } \\
\text { plan }\end{array}$ & $\begin{array}{l}\text { Students perform } \\
\text { calculations correctly, and } \\
\text { the steps are complete. }\end{array}$ & $\begin{array}{l}\text { Students are able to } \\
\text { re-explain the steps } \\
\text { of completion. }\end{array}$ & Data valid \\
\hline & Recheck & $\begin{array}{l}\begin{array}{l}\text { Students are still wrong } \\
\text { when }\end{array} \\
\text { drawing } \\
\text { conclusions. }\end{array}$ & $\begin{array}{l}\text { Students don't } \\
\text { understand how to } \\
\text { draw conclusions. }\end{array}$ & Data valid \\
\hline \multirow[t]{2}{*}{$\begin{array}{l}\text { Low Learning } \\
\text { Independence } 1\end{array}$} & $\begin{array}{l}\text { Understand the } \\
\text { problem }\end{array}$ & $\begin{array}{l}\text { Students are able to write } \\
\text { down what is known and } \\
\text { asked from the question. }\end{array}$ & $\begin{array}{l}\text { Students can } \\
\text { mention anything } \\
\text { that is known and } \\
\text { asked in the } \\
\text { question. }\end{array}$ & Data valid \\
\hline & $\begin{array}{ll}\text { Planning } & \text { a } \\
\text { settlement }\end{array}$ & $\begin{array}{l}\text { Students make an initial } \\
\text { plan by drawing } \\
\text { illustrations, but they are } \\
\text { not precise and do not }\end{array}$ & $\begin{array}{lr}\text { Students } & \text { only } \\
\text { compose } & \text { while } \\
\text { drawing } & \text { their } \\
\text { illustrations and are }\end{array}$ & Data valid \\
\hline
\end{tabular}




\begin{tabular}{|c|c|c|c|c|}
\hline & & write formulas. & $\begin{array}{l}\text { still confused by the } \\
\text { formula to be used. }\end{array}$ & \\
\hline & $\begin{array}{l}\text { Implementing a } \\
\text { plan }\end{array}$ & $\begin{array}{l}\text { Students do the right } \\
\text { calculations on number } 1 \\
\text { only. }\end{array}$ & $\begin{array}{l}\text { Students } r \\
\text { confused } \\
\text { doing calculations } \\
\text { on the numbers } 2 \\
\text { and 3. }\end{array}$ & Data valid \\
\hline & Recheck & $\begin{array}{l}\text { Students can re-examine } \\
\text { by drawing conclusions } \\
\text { but still go wrong. }\end{array}$ & $\begin{array}{l}\text { Students can't draw } \\
\text { conclusions and just } \\
\text { makeup when } \\
\text { answering them. }\end{array}$ & Data valid \\
\hline \multirow[t]{4}{*}{$\begin{array}{l}\text { Low Learning } \\
\text { Independence } 2\end{array}$} & $\begin{array}{l}\text { Understand the } \\
\text { problem }\end{array}$ & $\begin{array}{l}\text { Students can write down } \\
\text { anything they want and } \\
\text { ask questions. }\end{array}$ & $\begin{array}{l}\text { Students re-mention } \\
\text { known information } \\
\text { and are asked. }\end{array}$ & Data valid \\
\hline & $\begin{array}{l}\text { Planning } \quad \text { a } \\
\text { settlement }\end{array}$ & $\begin{array}{l}\text { Students only make } \\
\text { illustrations of the picture } \\
\text { is still wrong and does not } \\
\text { write the formula to be } \\
\text { used. }\end{array}$ & $\begin{array}{l}\text { Students are still } \\
\text { confused about what } \\
\text { to use to solve the } \\
\text { problem. }\end{array}$ & Data valid \\
\hline & $\begin{array}{l}\text { Implementing a } \\
\text { plan }\end{array}$ & $\begin{array}{l}\text { Students perform } \\
\text { calculations but are not } \\
\text { precise because they are } \\
\text { wrong in the formula and } \\
\text { in substituting the } \\
\text { numbers. }\end{array}$ & $\begin{array}{l}\text { Students find it } \\
\text { difficult to perform } \\
\text { calculations. }\end{array}$ & Data valid \\
\hline & Recheck & $\begin{array}{l}\text { Students don't check back. } \\
\text { Number } 2 \text { has checked } \\
\text { back by drawing } \\
\text { conclusions, but the } \\
\text { answer is not correct. }\end{array}$ & $\begin{array}{l}\text { Students still feel } \\
\text { confused at an } \\
\text { earlier stage, so it is } \\
\text { still wrong when } \\
\text { drawing } \\
\text { conclusions. }\end{array}$ & Data valid \\
\hline \multirow[t]{3}{*}{$\begin{array}{l}\text { Low Learning } \\
\text { Independence } 3\end{array}$} & $\begin{array}{l}\text { Understand the } \\
\text { problem }\end{array}$ & $\begin{array}{l}\text { Students can write down } \\
\text { anything they know and } \\
\text { ask. }\end{array}$ & $\begin{array}{l}\text { Students mention } \\
\text { what is known and } \\
\text { asked. }\end{array}$ & Data valid \\
\hline & $\begin{array}{l}\text { Planning } \quad \text { a } \\
\text { settlement }\end{array}$ & $\begin{array}{l}\text { Students write the initial } \\
\text { plan by making } \\
\text { illustrations according to } \\
\text { the problem, but the } \\
\text { picture is still wrong and } \\
\text { does not write the formula } \\
\text { to be used. }\end{array}$ & $\begin{array}{l}\text { Students do not } \\
\text { understand the } \\
\text { formula to be used. }\end{array}$ & Data valid \\
\hline & $\begin{array}{l}\text { Implementing a } \\
\text { plan }\end{array}$ & $\begin{array}{l}\text { Students are wrong in } \\
\text { doing calculations } \\
\text { because the formula used } \\
\text { is also wrong. }\end{array}$ & $\begin{array}{l}\text { Students still find it } \\
\text { difficult to do } \\
\text { calculations. }\end{array}$ & Data valid \\
\hline
\end{tabular}




\begin{tabular}{|l|l|l|l|l|}
\hline Recheck & $\begin{array}{l}\text { Students are wrong in } \\
\text { checking back. And the } \\
\text { conclusions obtained are } \\
\text { also still wrong. }\end{array}$ & $\begin{array}{l}\text { Students vata valid } \\
\text { confused about what } \\
\text { they are given. }\end{array}$ & . \\
\hline
\end{tabular}

Based on the results of the validity test conducted, researchers describe mathematical problem-solving skills in view of the learning independence of muhammadiyah sempor vocational students as follows:

Table 2. Mathematical Problem Solving Ability Reviewed from Student Learning Independence

\begin{tabular}{|c|c|c|c|}
\hline \multirow{2}{*}{$\begin{array}{c}\text { Indicators of } \\
\text { Mathematical Problem } \\
\text { Solving Skills }\end{array}$} & \multicolumn{3}{|c|}{ Learning Independence Category } \\
\hline & Tall & Keep & Low \\
\hline $\begin{array}{l}\text { Understand the } \\
\text { problem }\end{array}$ & $\begin{array}{l}\text { Students are already } \\
\text { able to understand the } \\
\text { problem by writing } \\
\text { down important } \\
\text { information that is } \\
\text { what is known and } \\
\text { asked appropriately. }\end{array}$ & $\begin{array}{l}\text { Students are already } \\
\text { able to understand } \\
\text { the problem by } \\
\text { writing down what } \\
\text { is known and asked } \\
\text { in the question. }\end{array}$ & $\begin{array}{l}\text { Students are } \\
\text { already able to } \\
\text { understand the } \\
\text { problem by } \\
\text { writing down what } \\
\text { is known and } \\
\text { asked in the } \\
\text { question. But the } \\
\text { writing is still the } \\
\text { same. }\end{array}$ \\
\hline Planning a settlement & $\begin{array}{l}\text { Students are already } \\
\text { able to plan the } \\
\text { completion by } \\
\text { writing mathematical } \\
\text { formulas } \\
\text { appropriately and can } \\
\text { make illustrations } \\
\text { according to the } \\
\text { problem item. }\end{array}$ & $\begin{array}{l}\text { Students are already } \\
\text { able to plan the } \\
\text { completion by } \\
\text { making illustrations } \\
\text { in the form of } \\
\text { images. But don't } \\
\text { write down the } \\
\text { formula to be used. }\end{array}$ & $\begin{array}{l}\text { Students are } \\
\text { unable to plan a } \\
\text { settlement. } \\
\text { Because it can not } \\
\text { write the } \\
\text { mathematical } \\
\text { formula, and the } \\
\text { illustration of the } \\
\text { picture is still } \\
\text { wrong. }\end{array}$ \\
\hline Implementing a plan & $\begin{array}{l}\text { Students are already } \\
\text { able to carry out the } \\
\text { plan by writing the } \\
\text { calculation steps } \\
\text { according to } \\
\text { mathematical } \\
\text { formulas that have } \\
\text { been made correctly } \\
\text { and systematically. }\end{array}$ & $\begin{array}{l}\text { Students are already } \\
\text { able to carry out the } \\
\text { plan by applying } \\
\text { mathematical } \\
\text { formulas correctly. }\end{array}$ & $\begin{array}{l}\text { Students are } \\
\text { unable to write } \\
\text { down the } \\
\text { calculation steps } \\
\text { because they are } \\
\text { still wrong with } \\
\text { the formula they } \\
\text { use so as to } \\
\text { produce incorrect } \\
\text { answers. }\end{array}$ \\
\hline Recheck & $\begin{array}{l}\text { Students can re- } \\
\text { examine by drawing } \\
\text { conclusions and } \\
\text { double-checking }\end{array}$ & $\begin{array}{l}\text { Students were } \\
\text { unable to check } \\
\text { back. The } \\
\text { conclusions are still }\end{array}$ & $\begin{array}{l}\text { Students are } \\
\text { unable to re- } \\
\text { examine the } \\
\text { conclusions }\end{array}$ \\
\hline
\end{tabular}




\begin{tabular}{|l|l|l|l|} 
& $\begin{array}{l}\text { whether the answer is } \\
\text { in accordance with } \\
\text { the question given. }\end{array}$ & $\begin{array}{l}\text { written wrong, and } \\
\text { I doubt the } \\
\text { conclusions. }\end{array}$ & $\begin{array}{l}\text { obtained because } \\
\text { they are having } \\
\text { difficulty at the } \\
\text { stage of } \\
\text { implementing the } \\
\text { plan. }\end{array}$ \\
\hline
\end{tabular}

\section{Conclusion}

Based on the results of research that has been carried out related to mathematical problemsolving ability in terms of the learning independence of muhammadiyah sempor vocational school students during the covid-19 pandemic, it was concluded that students with high learning independence during the covid-19 pandemic could already solve the problem well. Students can write down what is known and asked clearly by writing down only the important points. Students also know the formula to be used and can make illustrations in the form of images well. When doing calculations, groups of students with high learning independence can write down the steps of calculation well and systematically so as to produce the correct answer. Students of high learning independence can also re-examine by drawing the correct conclusions because they have checked from the first stage to the stage of doing calculations whether the answer to the conclusion is in accordance with what is asked. Based on this, students of high learning independence have been able to meet the stages of solving mathematical problems, namely understanding problems, planning solutions, implementing plans, and re-examining. During the interview, the student can explain the settlement steps clearly.

Students with moderate learning independence during the covid-19 pandemic are able to write down important information that is known and asked even though the sentence used is still the same as the problem. But it's still understandable. At the stage of planning completion, students can make illustrations in the form of images well even though they have not written the formula that will be used for the next stage. Because at the time of the interview, they said that they did not write the formula because it was directly applied to the plan. They can also perform calculation steps correctly and systematically. The formula used is right so that it produces the right answer. When re-examining, most students are still wrong when concluding. Because students do not double-check whether the answer is following what is asked, students with learning independence fulfill three indicators of mathematical problem-solving skills: understanding problems, planning solutions, and implementing plans.

Students with low learning independence during the covid-19 pandemic have been able to understand the problem. Students can write down anything they. At the stage of planning the completion of the group of students, low learning independence already makes images, but the welcome images are not appropriate. They also do not write down the formula to be used because during the interview said that they do not know what formula is used. Because in the previous stage, students do not know how the formula will be used, then at the stage of implementing the plan, the answers produced by students are also wrong. And the calculation steps are still wrong. Students can't draw conclusions. Therefore, students of low learning independence are only able to reach the stage of understanding the problem only. 


\section{References}

[1] Sulistyani, D., Roza, Y., \& Maimunah, M. (2020). Relationship of Learning Independence with Mathematical Problem-Solving Ability. Journal of Mathematics Education, 11(1), 1-12.

[2] Mawaddah, S., \& Anisah, H. (2015). Students' mathematical problem-solving skills on math learning using generative learning models in junior high. EDU-MAT: Journal of Mathematics Education, $3(2)$.

[3] Ansori, Y., \& Herdiman, I. (2019). The effect of learning independence on the mathematical problem-solving abilities of middle school students. Journal of Medives: Journal of Mathematics Education IKIP Veteran Semarang, 3(1), 11-19.

[4] Purnamasari, I., \& Setiawan, W. (2019). Analysis of Mathematical Problem-Solving Skills of Junior High School Students on SPLDV Materials Reviewed from The Initial Ability of Mathematics. Journal of Medives: Journal of Mathematics Education IKIP Veteran Semarang, 3(2), 207-215.

[5] Lestari, I., Andinny, Y., \& Mailizar, M. (2019). The Influence of Situation-Based Learning Model and Learning Independence on Mathematical Problem-Solving Skills. JNPM (National Journal of Mathematics Education), 3(1), 95-108.

[6] Rahmayani, D. (2020). Application of Reciprocal Teaching Learning to Improve Mathematical Communication Skills and Student Learning Independence. Pasundan Journal of Mathematics Education Journal of Mathematics Education, 3(1)

[7] Sariningsih, R., \& Kadarisma, G. (2016). Improving Mathematical Creative Thinking Skills and Learning Independence of Junior High School Students Through Ethnomamatics-based Scientific Approach. Scientific Journal P2M STKIP Siliwangi, 3(1), 53-56.

[8] Alinurdin, A., \& Prabowo, A. S. (2021). The influence of the use of smartphones and virtual classes on the independence of learning in the pandemic period of public high school students in two cities south of tangerang. Wiyatamandala, 1(1), 66-75.

[9] Amam, A. (2017). Assessment of the mathematical problem-solving abilities of junior high school students. Theorem: Mathematical Theory and Research, 2(1), 39-46.

[10] Ambiyar, A., Aziz, I., \& Delyana, H. (2020). Relationship of Student Learning Independence Towards Students' Mathematical Problem-Solving Abilities. Journal of Scholar: Journal of Mathematics Education, 4(2), 1171-1183. 